\title{
Articles
}

The Person and the Challenges

Volume 9 (2019) Number 1, p. 5-21

DOI: http://dx.doi.org/10.15633/pch.3358

Józef Marecki

ORCID: https://orcid.org/0000-0002-2170-4950

Pontifical University of John Paul II in Krakow, Poland

\section{From the Pontifical Faculty of Theology in Krakow to the Pontifical University of John Paul II in Krakow. Part 1: 1954-1982}

\begin{abstract}
In 1954, arbitrarily and without consulting with the Catholic Church, the communist authorities transferred the Faculties of Theology of the Jagiellonian University and the University of Warsaw to a new university that they had created without a canonical mandate - the Academy of Catholic Theology in Warsaw. Instead of accepting the Polish communists' unilateral decision, the Holy See transferred the rights of the Faculty of Theology in Krakow to the Archdiocesan Major Seminary, whose faculty eventually was given the right to have the adjective "Pontifical" in its title. Although it did not have authority from the state, it continued to offer post-secondary education and bestow academic titles upon its graduates. On the basis of this, Pope John Paul II, who as the Archbishop of Krakow was not only officially its great chancellor but also its promoter and special custodian, established the Pontifical Academy of Theology in 1981. This article presents the history of the Pontifical Faculty of Theology in 1954-1982. Its activity in later years as the Pontifical Academy of Theology, which in 2009 became the Pontifical University of John Paul II, will be presented in the second part of this text.
\end{abstract}




\section{Keywords}

Repression of the Catholic Church in Poland, Catholic education, theology, Academy of Catholic Theology, Pontifical Academy of Theology, Faculty of Theology of the Jagiellonian University.

\section{The Context}

The history of educating theologians and academic activity in the field of theology in Krakow dates back to the late fourteenth century. Upon the request of King Władysław and his Queen Jadwiga, on January 11, 1397, Pope Boniface IX issued the bull Eximiae devotionis affectus, which founded the Faculty of Theology at the University of Krakow, which had been established by King Casimir III the Great in $1364 .{ }^{1}$ Despite great historical turmoil, political events, and wars, this faculty continued to function uninterrupted up until $1954 .^{2}$

On August 11, 1954, upon a decision of the Council of Ministers (Resolution 591/54) ${ }^{3}$ - without any consultation with the representatives of the Catholic Church - this faculty (referred to in this resolution as the Faculty of Catholic Theology) was separated from the Jagiellonian University in Krakow, and on September 1 of that year it was merged with the newly-formed Academy of Catholic Theology in Warsaw. Although the resolution of the Council of Ministers indicated that the faculty would continue its activity at the Warsaw academy, as initially confirmed by the statute of the Academy of Catholic Theology, it meant

${ }^{1}$ For the original text of the bull, see: Archive of the Jagiellonian University in Krakow [henceforth AUJ], parchment 19. For the Polish translation of the bull, see: A. Kubiś, Papieski Wydział Teologiczny w Krakowie w latach 1954-1981, Kraków 2005, p. 23.

${ }^{2}$ For more on the topic of the history of the Jagiellonian University's Faculty of Theology, see: J. N. Fijałek, Studya do dziejów Uniwersytetu Krakowskiego i jego Wydziału Teologicznego $w$ XV wieku. W pięćset letnia rocznicę założenia wydziału teologicznego w Krakowie, Kraków 1898, passim; M. Markowski, Dzieje Wydziału Teologii Uniwersytetu Krakowskiego w latach 1397-1525, Kraków 1996, passim; Wydział Teologiczny w Krakowie 1397-1997. Księga Jubileuszowa, ed. S. Piech, Kraków 1997, passim; A. Kubiś, Papieski Wydział Teologiczny w Krakowie 1954-1981, in: Wyższe szkolnictwo kościelne w Polsce. Wizja Kardynała Karola Wojtyły i jej realizacja, Kraków 2002, pp. 9-59, 51-164 (source material); A. Kubiś, Papieski Wydział..., passim (numerous source materials after each chapter).

${ }^{3}$ For the original text of the resolution, see: AUJ, File No. WT II.27; print: Państwowe prawo wyznaniowe Polskiej Rzeczypospolitej Ludowej, ed. M. Fąka, Warszawa 1978, pp. 124-125. 
the de facto closure of the faculty. Students were no longer allowed to continue their studies at university level, ${ }^{4}$ and only part of the staff were transferred to the Academy of Catholic Theology. Slightly earlier, at the start of the 1950-1951 academic year, the number of students admitted to the Krakow Faculty of Theology was limited, but seminarians who had not been accepted to the faculty could participate in the lectures as non-certified students. Restrictions on the participation of so-called non-certified students were introduced only in the 1953-1954 academic year. Thus some seminarians were denied access to lectures. Upon the decision of the authorities of the Archdiocesan Major Seminary in Krakow, the Studium Domesticum was organized. From the moment of the "liquidation" of the Faculty of Theology, all the seminarians participated in this Studium. ${ }^{5}$ The program of lectures in the Studium was modeled on the arrangement that had previously functioned at the Faculty of Theology. The only difference was that students were unable to receive the title of Master of Arts, even though seminarians prepared dissertations that were equivalent to Master of Arts theses. ${ }^{6}$ It should be added that the early 1950 s were a time of intense struggle against the Catholic Church, as witnessed not only by the liquidation of Catholic education at all levels, the Catholic press and publishing houses, and various other Church institutions, but it was also a time when many bishops, including Cardinal Stefan Wyszyński, the primate of Poland, as well as hundreds of priests and members of religious orders were isolated (in reality, interned and imprisoned).

Church authorities did not accept this injurious decision and undertook steps to save the achievements and legacy of the oldest theological academic center in Poland. Archbishop Eugeniusz Baziak, the apostolic administrator of the Archdiocese of Krakow, ${ }^{7}$ effectively intervened with the Holy See, which

4 To read about the attitudes of the students of the Faculty of Theology of the Jagiellonian University after the "transfer" of this faculty to Warsaw, see: Archive of the Metropolitan Major Seminary in Krakow, no file no., Chronicle vol. 1, p. 358nn.

${ }_{5}$ M. Myrcha, Zagadnienia prawne Akademii Teologii Katolickiej, "Polonia Sacra” 7 (1955), pp. 7-77; S. Nowak, Jak wspominam Krakowskie seminarium duchowne [in:] Seminarium duchowne w Krakowie: 400-lecie, ed. J. Guzdek, F. Ślusarczyk, Kraków 2001, pp. 154-155; A. Kubiś, Papieski Wydział..., p. 18, 55; oral account by Rev. S. Koperek, Krakow, 10 IV 2019.

${ }^{6}$ For more on this topic, see: A. Kubiś, Papieski Wydział..., p. 60 (based on the account of Rev. J. Chmiel), 68; see: S. Koperek, Wkład Ks. Prof. Wacława Schenka w Papieski Wydziat Teologiczny w Krakowie, Ruch Biblijny i Liturgiczny 1983, nr 6, p. 502.

${ }^{7}$ K. Krasowski, Biskupi katoliccy II Rzeczypospolitej. Słownik biograficzny, Poznań 1996, pp. 28-29; J. Waligóra, Cierpiący pasterz. Ks. arcybiskup - metropolita lwowski Eugeniusz Baziak (1890-1962), Rzeszow 2013. 
had not been informed of this unusual incident either by the state authorities or by the university's administration. On December 16, 1959, the Sacred Congregation of Seminaries and Universities of Studies issued a decree confirming the existence of the Faculty of Theology in Krakow as a Church institution. Several months earlier, Rev. Prof. Ignacy Różycki ${ }^{8}$ prepared the first draft of the "Statute of the Faculty of Theology of Queen Jadwiga in Krakow." In later years, updated versions of the statute were prepared. It was introduced after having been approved by the Holy See. The practical activity of the Faculty of Theology was based around the lecturers and students of the Archdiocesan Major Seminary in Krakow; these included both the students of this seminary as well as seminarians belonging to religious orders. The headquarters of the faculty administration, the registrar's office and the secretariat, were also found in the seminary building after the original headquarters of the Faculty of Theology in Collegium Novum had been seized in 1954. Lectures and other coursework were held in accordance with the university practice of the Faculty of Theology. ${ }^{10}$

It should be noted that John Paul II, who personally witnessed the liquidation of the Faculty of Theology of the Jagiellonian University, and many years later put efforts into reactivating it, frequently referred to this event in his public speeches. During a meeting with the Senates of the Jagiellonian University and the Pontifical Academy of Theology on June 8, 1997, in St. Anne's Collegiate Church to mark the 6ooth anniversary of the Faculty of Theology, the Pope said: "[...] I have a close connection to this Faculty because of my studies in philosophy and theology during the war, which were therefore underground studies, and later through my doctorate and habilitation. Today, I have before my eyes above all the years of dramatic struggles for the existence of the faculty during the time of the communist dictatorship. I personally participated in these struggles as the Archbishop of Krakow. This painful period is fully deserving of reliable documentation and in-depth historical study. The Church never accepted the fact of the unilateral and unjust liquidation of the Faculty

${ }^{8}$ G. Ryś, Różycki Ignacy, in: Słownik polskich teologów katolickich 1981-1993, vol. 8: a-z, Warszawa 1995, pp. 494-495.

9 Archive of the Pontifical University of John Paul II in Krakow [henceforth Ar UPJP II], file no. WT-100.

${ }^{10}$ For more on this topic, see: A. Kubiś, Papieski Wydział..., pp. 61-64, 87nn; see: S. Nowak, Jak wspominam Krakowskie seminarium duchowne, in: Seminarium duchowne w Krakowie: 400-lecie, ed. J. Guzdek, F. Ślusarczyk, Kraków 2001, pp. 154-155. 
by the state authorities of the time. It did everything it could so that the Krakow university community would not be deprived of an academic study of theology. Despite many difficulties and harassment from the authorities, the Faculty existed at the Krakow seminary, first as the Pontifical Faculty of Theology. Eventually, this institution matured so that a Pontifical Academy of Theology could be established in Krakow as a university with three faculties, being the moral heir to the centuries-old Faculty of Theology of the Jagiellonian University. Thus today, on the occasion of this jubilee ceremony, we should thank God not only for allowing us to defend the great spiritual good of the Faculty of Theology, but also for having been able to expand it and give it a new, even richer academic form! Thus the Pontifical Academy of Theology, PAT for short [Polish: Polska Akademia Teologiczna] along with other Catholic universities in our homeland, have contributed to the development of Polish culture and scholarship, at the same time remaining a unique witness to our age, an age of the struggle of theological universities to be present in the academic landscape of today's Poland [...]". ${ }^{11}$

It is worth recalling that both the Church community in Krakow and the Jagiellonian University made attempts at bringing the Faculty of Theology back to its former mother university. Professors and lecturers from both the Jagiellonian University and the Faculty of Theology were engaged in this. It appears that one of the first initiatives was undertaken on November 16, 1956, by Prof. Jan Hulewicz at a meeting of the Regional Committee of the National Front in Krakow. He demanded that the university be given back its publisher and the reinstatement of faculties that had been separated from the mother university: medicine, agriculture, and theology. This postulate was supported by other professors both during university meetings and during pre-election rallies. This matter was discussed on several occasions at the meetings of the Senate of the Jagiellonian University (including on February 22, 1957, and April $26,1957)$, which adopted a resolution on the need to reactivate the teaching of theology at the Krakow university, and provided factual and pertinent arguments in discussions with state agents. Similarly, the topic of the return of the above-discussed Faculty was postulated by the members of the Council of the Faculty of Law (February 12, 1957). The topic of the return of the Faculty of Theology to the Jagiellonian University was also the subject of texts published

11 Papież Jan Pawet II na spotkaniu z okazji 600-lecia Wydziału Teologicznego UJ, in: J. Ziejka, Jan Paweł II i polski świat akademicki, Kraków 2014, p. 49. 
in "Tygodnik Powszechny", which in the fall of 1956 had been allowed to function in the sphere of the press again. This topic was discussed by Stanisław Stomma ${ }^{12}$ and Rev. Ignacy Różycki, among others. ${ }^{13}$ Furthermore, Member of Parliament Zbigniew Makarczyk from the Znak Parliamentary Circle spoke in favor of restoring the Faculty of Theology at the Jagiellonian University (on July 12, 1957). ${ }^{14}$ Unfortunately, the Communist Party press, including "Dziennik Polski", published articles denying the need for the Faculty to return to the structures of the Jagiellonian University. It is unnecessary to cite the arguments of the author of the article. It is enough to note that the author argued in favor of the removal of theology from the Krakow university by referring to the need to separate Church and state and to the growing secularization of society. ${ }^{15}$ This article is a classic example of the repetition of theses invented by the Communist Party propaganda machine.

Efforts to bring the Faculty of Theology back to the Jagiellonian University were also undertaken by lecturers from this Faculty and theologians belonging to the Polish Theological Society. In a resolution directed to the Presidium of the Council of Ministers adopted on November 21, 1956, the members of the society requested that the resolution from two years before be revoked. Less than two weeks later, on December 3 of that year, sixteen former lecturers from the Faculty of Theology called upon the Senate of the Jagiellonian University and its rector Prof. Zygmunt Grodziński ${ }^{16}$ to support the efforts to bring the Faculty back to the university. They renewed their request on January 25, 1957. They lobbied to separate the "Krakow Faculty" from the structures of the Academy of Catholic Theology, making use of the fact of the separation of the Faculty of Theology from the Jagiellonian University and its transfer to Warsaw. Both the Council of the Faculty of Theology and the Faculty of Christian Philosophy supported the requests of the former lecturers of the Faculty of Theology of the Jagiellonian University (September 1956). Furthermore, the Senate of the Academy of Catholic Theology supported the

12 S. Stomma, Mądrość tradycji, “Tygodnik Powszechny” (1956), nr 2 (from 13 I 1956).

13 I. Rożycki, Wydział królowej Jadwigi, “Tygodnik Powszechny” (1957), nr 5 (from 3 II 1957).

14 Z. Makarczyk, Sprawy katolików. Mowa wygłoszona w Sejmie PRL dnia 12 lipca 1957 r., “Tygodnik Powszechny” (1957), nr 29, p. 2.

15 K. Staniek, Uniwersytet i teologia, "Dziennik Polski” (1957), nr 124 (from 26-27 V 1957).

16 A. Śródka, Uczeni polscy XIX-XX stulecia, vol. 1: A-G, Warszawa 1994, pp. 585-586. 
return of the Faculty to the structures of the Krakow university (December 12, 1956). ${ }^{17}$ Krakow theologians also asked the bishops of Poland to support the initiative. This initiative was strongly supported by Cardinal Stefan Wyszyński, the primate of Poland. ${ }^{18}$ Unfortunately, these efforts did not bring the desired effects. ${ }^{19}$ All the efforts by the university community turned out to be futile, because the Ministry of Higher Education, which decided to maintain the status accepted in a resolution of the Council of Ministers from August 11, 1954, had a different aim.

Karol Wojtyła was an especially important patron of the Faculty of Theology, first as Vicar General and Vicar Capitular of the Archdiocese (19621964), next as the Archbishop of Krakow (1964-1978), and, finally, as head of the Catholic Church, Pope John Paul II (1978-2005). In 1963, the Holy See gave him the right to grant the degree of Licentiate of Sacred Theology (canonical degree) as an academic title. ${ }^{20}$ His concern for the proper functioning of the Faculty was accompanied by efforts to concentrate persons from various academic milieus around this center and undertaking efforts to bind the Faculty to various Church and academic institutions. In the latter case, one could mention, for example, the attempts at bringing the "Our Future" Publishing Institute existing under the auspices of the Congregation of the Mission closer to the Faculty. ${ }^{21}$ It should be added that in 1963 , or the following year, Bishop Karol Wojtyła, who, as the Vicar Capitular at the time, managed the Archdiocese and directly looked after the activity of the Faculty of Theology, recommended that its title include the adjective

17 See: Ar UPJP II, file no. SP-4. Rev. Władysław Wicher: Accomplishments (ibid., resolutions, reminder letters, and correspondence).

18 Ibid., file no. SP-4. Rev. Eugeniusz Florkowski: Accomplishments. Protocol of a meeting of a delegation of professors of the Faculty of Theology of the Jagiellonian University with Cardinal S. Wyszyński, Krakow, 18 VIII 1957.

19 M. Barcik, Próba przywrócenia Wydziału Teologicznego na Uniwersytecie Jagiellońskim (1956-1957), "Studia Historyczne" 2000, vol. 43, pp. 665-678 (for an amended version of the text, see: A. Kubiś, Papieski Wydział..., pp. 33-48).

20 See: A. Kubiś, Papieski Wydział..., p. 77 (there is a copy of the letter of Bishop K. Woityła to the rector of the Archdiocesan Major Seminary in Krakow Rev. E. Florkowskiego, Kraków, 24 V 1963).

${ }^{21}$ J. Marecki, W służbie przeszłości i nauki. Wydział Historii i Dziedzictwa Kulturowego Uniwersytetu Papieskiego Jana Pawła II w Krakowie (dawniej Wydział Historii Kościoła Papieskiej Akademii Teologicznej w Krakowie), Kraków 2011, p. 25. 
"Pontifical." ${ }^{22} \mathrm{He}$ also tried to ensure that meetings of the Faculty Council were held regularly, as occurs in academia. ${ }^{23}$

On June 23, 1963, nine years after the Faculty of Theology had been removed from university structures, a meeting of the Faculty Council, under the leadership of the rector of the seminary, Rev. Eugeniusz Florkowski, was held. ${ }^{24}$ In all likelihood, this was the first official meeting of professors from the Faculty who did not begin work at the Academy of Catholic Theology. ${ }^{25}$ From that point, meetings of the Faculty Council took place regularly, every few months. Academic matters were the main topic of the meetings.

On February 12, 1964, a meeting of the Faculty Council took place with the participation of the recently installed Archbishop of Krakow, Archbishop Karol Wojtyła. It is worth noting that during this meeting the problems related to the development of theology in a new political and social reality were discussed. As lecturers and students of what would become the Pontifical Faculty of Theology have frequently noted, Archbishop Karol Wojtyła emphasized that just the staff and members of the Faculty of Theology and he himself were the heirs and continuators of the university specialization. Mapping out the direction in which the faculty would develop, he said that "we can develop the future on the same principles as before." 26 The archbishop did not consent to the solutions that were proposed by the communist government by closing the Faculty of Theology at the Jagiellonian University and creating the Academy of Catholic Theology in Warsaw without the clear agreement of Church authorities. He believed that the basic rights to liberty and the independence of the Catholic Church had been violated. In order to be able to develop and have an impact on a Catholic society, theology must be free of any pressures and dependence on secular authorities, especially those that are of a secularist nature and have Marxist

${ }^{22}$ Ar UPJP II, file no. PWT-0022, Protocols from the meetings of the Council of the Pontifical Faculty of Theology, vol. 1, k. 4-4v (Protocol no. 1 from the meeting of the Council of the Faculty of Theology, 25 VI 1963).

${ }^{23}$ See: Ibid., vol. 1, passim.

${ }^{24}$ A. Kubiś, Ks. Prof. Dr Eugeniusz Florkowski (w 50-lecie świeceń kapłańskich), "Ruch Biblijny i Liturgiczny" 1976, nr 1, pp. 1-9; Tenże, Ks. prof. dr Eugeniusz Florkowski - uczony i pedagog, "Polonia Sacra" 2003, nr 12, pp. 229-239.

${ }^{25}$ Ibid., k. 4-4v (Protocol no. 1 from the meeting of the Council of the Faculty of Theology, 25 VI 1963).

${ }^{26}$ Ibid., k. 9 (Protocol no. 4 from the meeting of the Council of the Faculty of Theology, 12 II 1964). 
tendencies. He emphasized this on numerous occasions during meetings with faculty from the future Pontifical Faculty of Theology. ${ }^{27}$

After the council's meeting on September 30, 1965, the name "The Council of the Pontifical Faculty with a Specialization in Theology" appears in the protocols. ${ }^{28}$ When possible, the archbishop participated in the council meetings. In a protocol of the council dated June 10, 1968, Cardinal Karol Wojtyła, as was noted in the protocol, "notes the 1959 decrees [sic!] establishing the faculty. He says that the faculty has been established as a purely Church institution independent of Church authorities." ${ }^{29}$ It is worth emphasizing that during the aforementioned council meeting those in attendance unanimously voted to change its name from the Pontifical Specialization in Theology to the Pontifical Faculty of Theology.

In late 1969, an internal reorganization took place at the Pontifical Faculty of Theology, dividing it into sections (theology, philosophy, and canon law). The theology section was divided into four specializations (Biblical, dogmatic, moral, and historical theology). Each specialization in theology, philosophy, and canon law was given several chairs. In total, thirty chairs were proposed. ${ }^{30}$ There were plans to establish even more chairs in the future. I recall the above because, in a later period, the activity of the Pontifical Academy of Theology and its organization were based on the agreements from 1969 and 1975, when during one of the Faculty Councils (September 14, 1975) it was decided to establish the Faculty of Philosophy ${ }^{31}$ and the Historical Institute. ${ }^{32}$ Furthermore, the course

27 Oral account by Prof. Dr. Hab. Roman M. Zawadzki, Krakow, 26 IX 2017.

${ }^{28}$ Ar UPJP II, file no. PWT-0022, Protocols from the meetings of the Council of the Pontifical Faculty of Theology, vol. 1, k. 29v (Protocol no. 13 from the meeting of the Council of the Faculty of Theology, 30 II 1965).

${ }^{29}$ Ibid., Protocols from the meetings of the Council of the Pontifical Faculty of Theology in Krakow (10 VI 1968-25 VI 1974); Ibid., vol. 2, pp. 4-5 (Protocol 28 from the meeting of the Council of the Pontifical Faculty of Theology on June 10, 1968).

30 Ibid., file no. PWT-012, Organization of the Faculty.

31 On December 23, 1976, the Congregation for Catholic Education issued a decree establishing the Pontifical Faculty of Theology in Krakow; however, the Institute of Philosophy was ultimately established on February 18, 1978. See: Ibid., no file no., Decree Establishing the Pontifical Faculty of Theology in Krakow.

32 Ibid., file no. WT-01, Organizational drafts. Draft of the organizational structure and activity of the Queen Jadwiga Institute of History at the Pontifical Faculty of Theology. Ed. Roman Zawadzki (17 IV 1975). Ibid. other drafts of regulations; see: J. Marecki, W stużbie przeszłości..., pp. 25-27. 
offered coursework such as the pastoral course, the Catechetical Course, the Course on Theology of the Family, the Course on Theology of the Internal Life, the Course on Contemporary Thought, and the Liturgical Institute. ${ }^{33}$ In 1981, an Institute of Theology was established in Czestochowa. ${ }^{34}$ Several diocesan and religious seminaries as well as the Theological Institute in Tarnow collaborated with the Faculty (agreement dated February 22, 1975). ${ }^{35}$

I have mentioned, several times above, that seminarians who until 1954 attended lectures at the Faculty of Theology of the Jagiellonian University, after it had been transferred to Warsaw were forced to be educated as part of the Studium Domesticum. Lectures were mostly held by staff from the Faculty. Those professors who had moved to Warsaw returned to Krakow and began to teach seminarians. In the 1960s and 1970s, some of them were once again hired by the Academy of Catholic Theology. However, students of the Archdiocesan Major Seminary were not the only students of the Pontifical Faculty of Theology in Krakow. It has been mentioned above that numerous courses and institutes were organized with the participation of the Faculty. Other seminaries were also affiliated. The course for the canonical Licentiate of Sacred Theology was launched in 1964, naturally with the agreement of the Holy See, and the power to grant the licentiate was unparalleled at a global scale. In no other communist country was such a bold step permitted. There were a great many academic initiatives initiated and led by academic staff from the Faculty, including special lectures and speeches, symposiums and academic conferences, pastoral meetings in the pre-conciliar period (the Second Vatican Council) and participation in Krakow ministry in the archdiocesan synod, ${ }^{36}$ and participation with the Polish Theo-

${ }^{33}$ Archive of the Institute on the Family in Krakow, no file no., W. Półtawska, Struktura Instytutu Rodziny (18 I 1969); K. Bukowski, Studium Myśli Chrześcijańskiej, "Materiały Homiletyczne" (1980), nr 38, pp. 106-110; Euntes docete. XXV lat Instytutu Liturgicznego na Wydziale Teologicznym Papieskiej Akademii Teologicznej w Krakowie, ed. S. Koperek et. al., Krakow 1993, W. Gasidło, Duszpasterska troska Kardynała Karola Wojtyły o rodzinę, Kraków 1997, pp. 38-60; C. M. Sondey, Intelektualna i duchowa formacja osobowa katechetek, Kraków 1998, passim; J. Miecznikowski, Krakowski Instytut Liturgiczny, Kraków 2005, passim; A. Kubiś, Papieski Wydział..., pp. 102-114; see: Oral account by R. Zawadzki, Krakow 4 IV 2019.

${ }^{34}$ Ar UPJP II, no file no., Decree establishing the Institute of Theology in Czestochowa (3 V 1981); oral account by S. Koperek, Krakow, 10 IV 2019.

35 Ar UPJP II, no file no., Agreement Regarding Cooperation between the Pontifical Faculty of Theology in Krakow and the Institute of Theology in Tarnow (22 II 1975).

36 See: J. Marecki, Duszpasterski Synod Archidiecezji Krakowskiej 1972-1979 jako próba recepcji Soboru Watykańskiego II, [in:] Studia Soborowe. Historia i recepcja Vaticanum II, ed. 
logical Society as well as numerous international publishers and libraries. All this attests to exceptional academic and organizational vibrancy as well as to efforts in support of the milieu of the Pontifical Faculty of Theology in Krakow. ${ }^{37}$

It is also worth recalling numerous laypeople, including lecturers of the Jagiellonian University, who were engaged in the faculty's activity despite the threat of repression from the communist authorities. It is worth recalling, for example, Prof. Dr. Hab. Adam Vetulani. ${ }^{38}$ In the 1960 s, he was the only layperson affiliated with the faculty. He first participated in the session of the Council of the Pontifical Faculty of Theology on November 7, 1968. It was he who recommended collaboration with Prof. Wojciech Maria Bartel, ${ }^{39}$ who became permanently affiliated with the Faculty and was undeterred by potential repression from the communist authorities and the authorities of the Jagiellonian University. ${ }^{40}$ He was active in the faculty's activity and provided legal assistance in the editing of statutes, rulebooks, and official texts. It is also important to recall the teacher of ancient Greek and Latin, lecturer, and librarian of many years at the Faculty (as well as the major seminary), Mr. Tytus Górski, M.A., S.T.L, ${ }^{41}$ as well as Prof. Dr. Hab. Roman Maria Zawadzki, who for many years worked initially at the Faculty, and later at the Pontifical Academy of Theology.

During his last years in Krakow, Cardinal Karol Wojtyła put effort into the further development of the Faculty of Theology, the increase of the didactic and academic staff, and even the transformation of the faculty into an academy or other institution of an academic profile that could be recognized by state authorities. Unfortunately, the political climate of the time was not conducive

M. Białkowski, Torun 2014, pp. 609-635 (this contains information about the contribution of professors and lecturers of the Pontifical Faculty of Theology to the synod).

37 Oral account by R. Zawadzki, Krakow 4 IV 2019.

38 Adam Vetulani. 1901-1976, Krakow 2005.

39 For more on the activity of Prof. W. M. Bartel at the Pontifical Faculty of Theology and the Pontifical Academy of Theology, see: J. Marecki, Działalność prof. Wojciecha M. Bartla w krakowskiej uczelni teologicznej (an article printed in the memorial book dedicated to Prof. W. M. Bartel prepared by the Faculty of Canon Law of the Pontifical University of John Paul II in Krakow).

40 Ar UPJP II, file no. PWT-0022, Protocols from the meetings of the Council of the Pontifical Faculty of Theology, vol. 2, p. 10 (Protocol 31 of the session of the Council of the Pontifical Faculty of Theology in Krakow on November 7, 1968), p. 14 (Protocol 32 from the session of the Council of the Pontifical Faculty of Theology in Krakow on December 12, 1968).

${ }^{41}$ J. Bednarczyk, Pótwiecze działalności dydaktyczno-naukowej Profesora Tytusa Górskiego (Curriculum vitae), "FIDES - Biuletyn Bibliotek Kościelnych” (2000), nr 1-2, pp. 45-49. 
to discussions on this topic with the representatives of the authorities. The communist authorities argued that another post-secondary university with a Catholic profile (they had in mind the Catholic University of Lublin and the Academy of Catholic Theology) was not needed in Poland. ${ }^{42}$

The Pontifical Faculty of Theology in Krakow did not have legal personality and thus was not recognized by the state authorities. The faculty received its proper legal status from the Office on Religious Denominations on February $16,1981 .{ }^{43}$ Despite numerous and diverse difficulties, troubles and harassment from the state authorities (as attested by the lack of recognition of academic titles and degrees received at this Faculty, as well as the removal of the Faculty's name by censors from printed publications, including internal periodicals and Church communications), the Pontifical Faculty of Theology expanded its academic and didactic activity as an academic university. It is worth mentioning that between 1962 and 1982, 619 people received master's degrees, 182 received licentiates in sacred theology, and forty-one received doctorates from the Pontifical Faculty of Theology. Furthermore, twelve habilitations were defended, eleven persons became associate professors, and another fourteen became full professors. ${ }^{44}$ Beginning in 1969 , the Faculty published its own academic journal titled: "Analecta Cracoviensia", which due to state censorship was published as a periodical of the Polish Theological Society. ${ }^{45}$ It also belonged to the International Federation of Catholic Universities (FIUC), which was not without significance at the international level. ${ }^{46}$

The following led the Pontifical Faculty of Theology as deans: Rev. Prof. Dr. Hab. Eugeniusz Florkowski ([1961] 1964-1968), Rev. Prof. Dr. Hab. Stanisław

${ }^{42}$ Ar UPJP II, no file no., Correspondence of Cardinal Karol Wojtyła about the recognition of the Pontifical Academy of Theology; La Pontificia Facoltà di Teologia di Cracovia, "L'Osservatore Romano" 24 XI 1974, p. 2; Letter of the Archbishop of Krakow Cardinal Karol Wojtyła to the chairman of the Council of Ministers P. Jaroszewicz (Krakow, 18 II 1974), in: Wyższe szkolnictwo kościelne..., pp. 110-161; Oral account by R. Zawadzki, Krakow 4 IV 2019.

43 A. Kubiś, Papieski Wydział..., p. 341.

${ }^{44}$ Ibid., pp. 84-85, 118-121 (list of doctors), 208-210, 240-241 (list of habilitations and professorships).

${ }^{45}$ Ar UPJP II, no file no., Agreement Transferring Intellectual Property Rights of the journal Analecta Cracoviensia from the Polish Theological Association to the Pontifical Academy of Theology, (15 III 1993).

46 Papieska Akademia Teologiczna petnoprawnym członkiem FIUC, "Biuletyn PAT” 1983/84, nr 2, p. 4. 
Grzybek (1968-1974) ${ }^{47}$, and Rev. Prof. Dr. Hab. Marian Jaworski (1974-1982). ${ }^{48}$ They were assisted by vice-deans and secretaries of the faculty who provided the appropriate documentation. ${ }^{49}$

The history of the Pontifical Faculty of Theology was irrevocably changed by the election of Cardinal Karol Wojtyła to the Chair of St. Peter on October 16, 1978. Less than a year later, during his first pilgrimage to his native Poland, John Paul II met in the residence of Krakow bishops with the members of the Council of the Pontifical Faculty of Theology and the representatives of seminaries cooperating with this faculty on June 9, 1979. In a speech addressed to those present, the pope said that a university with three faculties would be established. ${ }^{50}$ The formation of a statute committee by the Council of the Pontifical Faculty of Theology was a kind of response to the Pope's project. After numerous sessions in 1980-1981, it presented the results of its work. The draft of the statute for the Pontifical Lateran University in Krakow was accepted at a meeting of the Council of the Pontifical Academy of Theology on June 23, 1981. After several amendments, it was presented to the Congregation for Catholic Education on July 29, 1981. ${ }^{51}$ The Congregation for Catholic Education accepted the statute of the Pontifical Academy of Theology in a decree dated December 8, 1983. Furthermore, in a letter addressed to the great chancellor of the new university, the prefect of the congregation Cardinal William Baum included certain comments on the topic of replacing the term "university" with "academy" in the statute, amendments to the preamble, and guidelines regarding the organization and functioning of the Faculty of Church History. ${ }^{52}$

47 T. Matras, Śp. (Circle No. Stanisław Grzybek (1915-1998), "Ruch Biblijny i Liturgiczny" (1999), nr 1, pp. 70-75; S. Mędala, Ks. prof. dr hab. Stanisław Grzybek (1915-1998), "Studia Theologiae Varsaviensia” (1999), nr 1, pp. 9-19.

48 P. Nitecki, Biskupi Kościoła w Polsce w latach 965-1999. Słownik biograficzny, Warsaw 2000, col. 179-180; K. Mikucki, Ksiądz Kardynał Marian Jaworski: działalność naukowa, zarys filozofii oraz niektóre aspekty relacji pomiędzy filozofią a teologia, "Zeszyty HistorycznoTeologiczne" (2013), nr 19, pp. 187-243.

49 Ar UPJP II, file no. PWT-0022, Protocols from the meetings of the Council of the Pontifical Faculty of Theology, vol. 1-5, passim.

${ }^{50}$ Ibid., Protocols from the meetings of the Council of the Pontifical Faculty of Theology, vol. 4, knlb. (Protocols from the session of the Council of the Pontifical Faculty of Theology in Krakow, 9 VI 1979).

51 Ibid., file no. BR-010, Statute.

52 A. Kubiś, Papieski Wydział..., pp. 384- 385; see: Oral account by R. Zawadzki, Krakow 4 IV 2019; Oral Account by Rev. S. Koperek, Krakow, 10 IV 2019. 
On October 8, 1981, Pope John Paul II established the Pontifical Academy of Theology from what had hitherto been the Pontifical Faculty of Theology in Krakow with three faculties: Theology, Philosophy, and Church History. In January of the following year, the first session of the professorial staff of what had been the Pontifical Faculty of Theology, where staff began to be divided into various faculties, took place. A Committee for the Organization of the Pontifical Academy of Theology in Krakow was formed..$^{53}$ On June 11, 1982, another session of the Council of the Pontifical Faculty of Theology was held. It took place upon the invitation of Archbishop Franciszek Macharski in the Krakow bishops' palace. The members of the council were divided into three groups according to academic specialization with the aim of constituting faculty councils with deans while confidential elections were held to elect the academy's authorities. Rev. Prof. Dr. Hab. Marian Jaworski was elected rector, while Rev. Prof. Dr. Hab. Adam Kubiś was named vice-rector. ${ }^{54}$ The Pontifical Academy of Theology officially began its activity at the start of the 1982-1983 academic year. ${ }^{55}$

\section{Bibliography}

\section{Primary sources}

Archive of the Jagiellonian University in Krakow

AUJ, parchment 19.

AUJ, File No. WT II.27

Archive of the Metropolitan Major Seminary in Krakow

no file no., Chronicle vol. 1.

Archive of the Pontifical University of John Paul II in Krakow

Ar UPJP II, file no. WT-100.

Ar UPJP II, file no. SP-4.

Ar UPJP II, file no. PWT-0022, Protocols from the meetings of the Council of the Pontifical Faculty of Theology, vol. 1.

${ }^{53}$ See: J. Marecki, $W$ stużbie przeszłości..., p. 29.

${ }^{54}$ Ksiądz profesor Adam Kubiś. Curriculum vitae, Krakow 2012.

${ }^{55}$ Ar UPJP II, file no. PWT-0022, Protocols from the meetings of the Council of the Pontifical Faculty of Theology, vol. 5, p. 193 (Protocol No. 167 from the meeting of the Council of the Pontifical Faculty of Theology in Krakow, 11 VI 1982); J. Marecki, W stużbie przeszłości..., p. 30; Oral account by Rev. S. Koperek, Krakow, 10 IV 2019. 
Ar UPJP II, file no. PWT-0022, Protocols from the meetings of the Council of the Pontifical Faculty of Theology, vol. 1-2.

Ar UPJP II, file no. PWT-012, Organization of the Faculty.

Ar UPJP II, file no. WT-01, Organizational drafts. Draft of the organizational structure and activity of the Queen Jadwiga Institute of History at the Pontifical Faculty of Theology. Ed. Roman Zawadzki (17 IV 1975).

Ar UPJP II, no file no., Agreement Transferring Intellectual Property Rights of the journal Analecta Cracoviensia from the Polish Theological Association to the Pontifical Academy of Theology, (15 III 1993).

Ar UPJP II, no file no., Decree establishing the Institute of Theology in Czestochowa (3 V 1981); oral account by S. Koperek, Krakow, 10 IV 2019.

Ar UPJP II, no file no., Agreement Regarding Cooperation between the Pontifical Faculty of Theology in Krakow and the Institute of Theology in Tarnow (22 II 1975).

Ar UPJP II, Protocols from the meetings of the Council of the Pontifical Faculty of Theology, vol. 4 (Protocols from the session of the Council of the Pontifical Faculty of Theology in Krakow, 9 VI 1979).

Ar UPJP I, file no. BR-010, Statute.

Ar UPJP II, no file no., Correspondence of Cardinal Karol Wojtyła about the recognition of the Pontifical Academy of Theology; La Pontificia Facoltà di Teologia di Cracovia, “L’Osservatore Romano" 24 XI 1974.

Ar UPJP II, file no. PWT-0022, Protocols from the meetings of the Council of the Pontifical Faculty of Theology, vol. 1-5.

Ar UPJP II, file no. PWT-0022, Protocols from the meetings of the Council of the Pontifical Faculty of Theology, vol. 5.

Ar UPJP II, file no. PWT-0022, Protocols from the meetings of the Council of the Pontifical Faculty of Theology, vol. 2.

\section{Books \& articles}

Adam Vetulani. 1901-1976, Krakow 2005.

Barcik M., Próba przywrócenia Wydziału Teologicznego na Uniwersytecie Jagiellońskim (1956-1957), "Studia Historyczne" (2000), vol. 43, pp. 665-678.

Bednarczyk J., Pótwiecze działalności dydaktyczno-naukowej Profesora Tytusa Górskiego (Curriculum vitae), "FIDES - Biuletyn Bibliotek Kościelnych" (2000), nr 1-2, pp. 45-49.

Bukowski K., Studium Myśli Chrześcijańskiej, “Materiały Homiletyczne” (1980), nr 38, pp. 106-110.

Euntes docete. XXV lat Instytutu Liturgicznego na Wydziale Teologicznym Papieskiej Akademii Teologicznej w Krakowie, ed. S. Koperek et. al., Krakow 1993.

Fijałek J. N., Studya do dziejów Uniwersytetu Krakowskiego i jego Wydziału Teologicznego w XV wieku. W pięćset letnia rocznicę założenia wydziału teologicznego w Krakowie, Kraków 1898. 
Gasidło W., Duszpasterska troska Kardynała Karola Wojtyły o rodzinę, Kraków 1997.

Koperek S., Wkład Ks. Prof. Wacława Schenka w Papieski Wydział Teologiczny w Krakowie, „Ruch Biblijny i Liturgiczny” (1983), nr 6, p. 502.

Krasowski K., Biskupi katoliccy II Rzeczypospolitej. Słownik biograficzny, Poznań 1996.

Ksiądz profesor Adam Kubiś. Curriculum vitae, Krakow 2012.

Kubiś A., Papieski Wydział Teologiczny w Krakowie w latach 1954-1981, Kraków 2005.

Kubiś A., Papieski Wydział Teologiczny w Krakowie 1954-1981, in: Wyższe szkolnictwo kościelne w Polsce. Wizja Kardynała Karola Wojtyły i jej realizacja, Kraków 2002, pp. 9-164.

Kubiś A., Ks. prof. dr Eugeniusz Florkowski - uczony i pedagog, "Polonia Sacra” (2003), nr 12, pp. 229-239.

Kubiś A., Ks. Prof. Dr Eugeniusz Florkowski (w 50-lecie świeceń kapłańskich), "Ruch Biblijny i Liturgiczny" (1976), nr 1, pp. 1-9.

Makarczyk Z., Sprawy katolików. Mowa wygłoszona w Sejmie PRL dnia 12 lipca 1957 r., "Tygodnik Powszechny" (1957), nr 29, p. 2.

Markowski M., Dzieje Wydziału Teologii Uniwersytetu Krakowskiego w latach 1397-1525, Kraków 1996.

Marecki J., W służbie przeszłości i nauki. Wydział Historii i Dziedzictwa Kulturowego Uniwersytetu Papieskiego Jana Pawła II w Krakowie (dawniej Wydział Historii Kościoła Papieskiej Akademii Teologicznej w Krakowie), Kraków 2011.

Marecki J., Duszpasterski Synod Archidiecezji Krakowskiej 1972-1979 jako próba recepcji Soboru Watykańskiego II, [in:] Studia Soborowe. Historia i recepcja Vaticanum II, ed. M. Białkowski, Toruń 2014, pp. 609-635.

Marecki J., Działalność prof. Wojciecha M. Bartla w krakowskiej uczelni teologicznej (an article will be printed in the memorial book dedicated to Prof. W. M. Bartel prepared by the Faculty of Canon Law of the Pontifical University of John Paul II in Krakow).

Matras T., Śp. Ks. Stanisław Grzybek (1915-1998), “Ruch Biblijny i Liturgiczny” (1999), nr 1, pp. 70-75.

Mędala S., Ks. prof. dr hab. Stanisław Grzybek (1915-1998), “Studia Theologiae Varsaviensia" (1999), nr 1, pp. 9-19.

Miecznikowski J., Krakowski Instytut Liturgiczny, Kraków 2005.

Mikucki K., Ksiądz Kardynał Marian Jaworski: działalność naukowa, zarys filozofii oraz niektóre aspekty relacji pomiędzy filozofia a teologia, "Zeszyty HistorycznoTeologiczne" (2013), nr 19, pp. 187-244.

Myrcha M., Zagadnienia prawne Akademii Teologii Katolickiej, "Polonia Sacra” 7 (1955), pp. 7-77.

Nitecki P., Biskupi Kościoła w Polsce w latach 965-1999. Słownik biograficzny, Warsaw 2000.

Nowak S., Jak wspominam Krakowskie seminarium duchowne, in: Seminarium duchowne w Krakowie: 400-lecie, ed. J. Guzdek, F. Ślusarczyk, Kraków 2001, pp. 154-155. 
Państwowe prawo wyznaniowe Polskiej Rzeczypospolitej Ludowej, ed. M. Fąka, Warszawa 1978.

Papieska Akademia Teologiczna pełnoprawnym członkiem FIUC, "Biuletyn PAT" 1983/84, nr 2, p. 4.

Papież Jan Pawet II na spotkaniu z okazji 600-lecia Wydziału Teologicznego UJ, in: J. Ziejka, Jan Paweł II i polski świat akademicki, Kraków 2014, p. 49.

Ryś G., Różycki Ignacy, in: Słownik polskich teologów katolickich 1981-1993, vol. 8: a-z, Warszawa 1995, pp. 494-495.

Sondey C. M., Intelektualna i duchowa formacja osobowa katechetek, Kraków 1998.

Staniek K., Uniwersytet i teologia, “Dziennik Polski” (1957), nr 124 (from 26-27 V 1957).

Stomma S., Mądrość tradycji, “Tygodnik Powszechny” (1956), nr 2 (from 13 I 1956).

Śródka A., Uczeni polscy XIX-XX stulecia, vol. 1: A-G, Warszawa 1994, pp. 585-586.

Waligóra J., Cierpiący pasterz. Ks. arcybiskup - metropolita lwowski Eugeniusz Baziak (1890-1962), Rzeszow 2013.

Wydział Teologiczny w Krakowie 1397-1997. Księga Jubileuszowa, ed. S. Piech, Kraków 1997. 